\title{
Lithuanian verbs in -auti and -uoti
}

\author{
FREDERIK KORTLANDT \\ Rijksuniversiteit Leiden
}

\begin{abstract}
The type in -uoti originally represents denominatives with stress on the suffix. The type in -auti represents denominatives which were stem-stressed before de Saussure's law operated. It follows that the suffix -au- was the unstressed variant of the suffix -uo-.
\end{abstract}

Scholars disagree about the question if the Lithuanian verbs in -auti and -uoti have a common historical source (e.g., Vaillant 1966, 353) or represent two distinct morphological types (e.g., Stang 1966, 364f.). We find no more than a single cognate type in other languages, viz. Latvian -uot, Old Prussian -aut, and Slavic -ovati. Stang admits that he cannot find a semantic distinction between the two Lithuanian formations. We may therefore look for an original complementary distribution.

Since both -áuti and -úoti (Latvian -uôt) are acute under the stress, we may exclude from consideration not only obviously recent words such as falsifikúoti and komandúoti and doublets such as pánčiuoti beside pánčioti 'hobble' and verbs in -uriuoti beside -urti, but also verbs where de Saussure's law would have operated if they had existed at that time. A review of Senn's list (1966, 270-73) now yields the elimination of 'Farbenbezeichnungen' such as bal̃tuoti 'show white' and juõduoti 'show black', which have a metatonical circumflex, and their evidently more recent variants baltúoti and juodúoti, which belong to the productive accent pattern. These can easily have arisen on the analogy of other denominatives. The same holds for the 'Lautmalende Bildungen auf -uliúoti oder -aliúoti', which may in their turn have furnished the model for the variant 'Diminutiv-Frequentativa auf -iniuoti' beside the verbs slidinéti 'slide' and stovinéti 'stand about'. This eliminates all stemstressed verbs in -uoti and leaves us with a large number of denominatives and a small number of deverbal formations in stressed -uoti. The large majority of the deverbatives signify 'Dahinbewegen, Hin- und Herbewegen' or 'von Lebewesen hervorgebrachtes Geräusch' and the rest may be derived from deverbal nouns, e.g. vadúoti 'liberate', cf. vãdas 'leader'. We may therefore conclude that the type in -uoti originally represents denominatives with stress on the suffix. 
Stem-stressed verbs in -auti have either a metatonical acute ( 6 deverbatives and 2 denominatives in Senn's list) or an original acute ( 1 deverbative and 2 denominatives), while the deverbatives in stressed -áuti may have shifted the stress in accordance with de Saussure's law (4 instances). Here again, we may suspect underlying deverbal nouns in the deverbatives. The denominatives in stressed -áuti have an acute root before the suffix in 3 out of 21 instances, viz. bernáuti 'work as a laborer', uogáuti 'gather berries', and jaunáuti 'be young'. These verbs can easily be analogical. I conclude that the type in -auti represents denominatives which were stem-stressed before de Saussure's law operated. It follows that the suffix -au-was the unstressed variant of the suffix -uo-.

The complementary distribution of the verbs in -auti and -uoti has important consequences for the historical phonology of East Baltic. While ${ }^{*}-e H u$ and *aHu- are clearly reflected in šiáure 'north' and sáule 'sun', respectively, we find e.g. plúostas beside pláustas 'ferry'. It is attractive to regard these words as the reflexes of stem-stressed and end-stressed forms of a single paradigm. The main objection to this view is that the $u$-diphthong is preserved in the stressed endings of the genitive sünaús 'son' < *ous and the original locative pusiä $\tilde{u}$ 'in half' $<{ }^{*}-\bar{e} u$, cf. OPr. pauson. The objection does not hold because the Žemaitian loc. sg. ending of the $u$-stems appears to reflect $*_{-} \bar{o}$ from earlier ${ }^{*}-\bar{o} u$ (cf. Stang 1966,75 ). This reflex is reminiscent of the Žemaitian dat. sg. ending of the $o$-stems ${ }^{*}-\bar{o}$ from ${ }^{*}-\bar{o} i$, which corresponds to $-u i$ and $-a i$ elsewhere, while the inst. pl. ending ${ }^{*}-o i s$ is reflected as *-ais. It may therefore be suggested that the 'long' diphthongs were preserved in final open syllables only and that the East Baltic monophthongization of stressed ${ }^{*} e i,{ }^{*} a i,{ }^{*} o i$ (cf. Kortlandt 1977, 323) had a counterpart in the development of stressed ${ }^{*} \bar{o} u$ to ${ }^{*} \bar{o}$ and unstressed ${ }^{*} \bar{o} u$ to $* a u$ except in word-final position. This development was motivated by the fact that the timbre distinction between ${ }^{*} \bar{o}$ and $* \bar{a}$ was preserved in stressed but not in unstressed syllables, except for the dat. sg. endings ${ }^{*}-\bar{o} i$ and ${ }^{*}-\bar{a} i$.

The theory advanced here offers a straightforward explanation for the difference between the regular type of spiáuti 'spit' and káuti 'kill', which have an $e$ - or $a$-coloring laryngeal, and the isolated verb šlúoti 'sweep', which can now be identified as having an $o$-coloring laryngeal. It is clear from OPr. rickawie 'rules' and pogerdawie 'preaches' that we have to start from a Balto-Slavic present stem *slow(i)e-, which reflects a secondary full grade $* \hat{k}$ leuH $3_{3-}$, beside an aorist stem ${ }^{*}$ śloHus- $<* \hat{k} l e H_{3} u s-$ and to assume a resyllabification in šlúoja 'sweeps', as in kraũjas 'blood', OPr. krawian, Skt. kravya-. The preterit šlãve may be analogical after dãve 'gave', which must probably be derived from the perfect $3 \mathrm{rd} \mathrm{pl.} \mathrm{*do'e} \mathrm{beside} 3 \mathrm{rd} \mathrm{sg}$. ${ }^{*} d \bar{o} u$ in a similar way as Slavic stojati beside Lith. stovéti 'stand' must be derived from *sta'-e'- on the basis of the perfect *stāu, *sta'e (cf. Kortlandt 1989, 111). 


\section{REFERENCES}

KortlandT, FrEDERIK. 1977. Historical laws of Baltic accentuation. Baltistica 13:2.319-30.

1989. Lithuanian statýti and related formations. Baltistica 25:2.104-12.

SENN, ALFRED. 1966. Handbuch der litauischen Sprache Bd. I. Heidelberg: Winter.

Stanci, Christian S. 1966. Vergleichende Grammatik der Baltischen Sprachen. Oslo, etc.: Universitetsforlaget.

VAILLANT, ANDRÉ. 1966. Grammaire comparée des langues slaves, III. Paris: Klincksieck. 